\title{
Can Viral Load Predict Liver Histology in Patients With Chronic Hepatitis B?
}

\author{
Ashraf Karbasi ${ }^{1}$, Behzad Bafandeh ${ }^{1}$, Seyed-Moayed Alavian ${ }^{1}$, Amin Saburi $^{2 *}$ \\ 1. Baqiyatallah Research Center of Gastroenterology and Liver Disease, Baqiyatallah University of Medical Sciences, Tehran, Iran \\ 2. Chemical Injury Research Center, Baqiyatallah University of Medical Sciences, Tehran, Iran
}

"Corresponding Author: Amin Saburi, MD, Chemical Injuries Research Center, Baqiyatallah University of Medical Sciences, Tehran, Iran Email: aminsaburi@yahoo.com

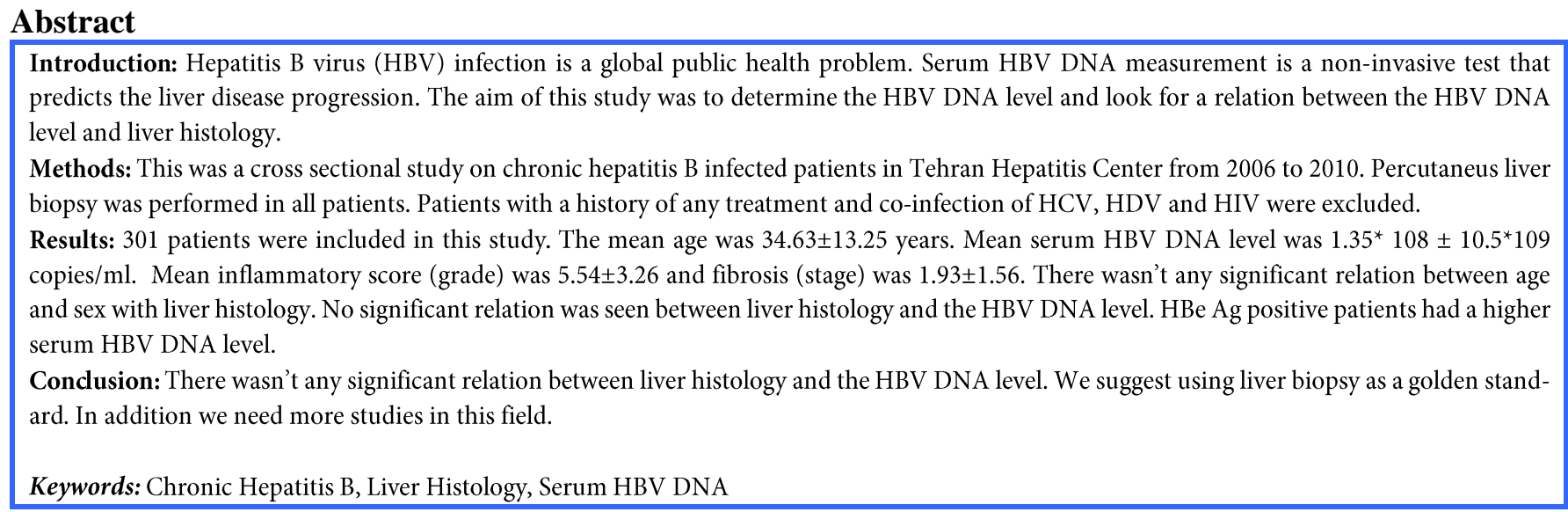

Article History: Received: 7 Sep 2014; Revised: 21 Oct 2014; Accepted: 12 Nov 2014

Cite this article as: Karbasi A, Bafandeh B, Alavian SM, Saburi A. Can viral load predict liver histology in patients with P00chronic Hepatitis B?. Int J Travel Med Glob Health. 2015;3(1):19-21.

\section{Introduction}

Chronic infection with hepatitis B virus (HBV) represents a worldwide health problem with continuing new infections being an important cause of liver disease, morbidity and mortality [1]. Around 400 million people worldwide, comprising $6 \%$ of the world population are chronically infected with the $\mathrm{HBV}$, and 2 billion people have serological evidence of past or present HBV infection [2]. $75 \%$ of patients with $\mathrm{CHB}$ are Asian [3] and the prevalence of the HBV infection in Iran is estimated to be $2.14 \%$ in the entire population [4]. The relationship between hepatitis $B$ viremia and progression to cirrhosis in chronic hepatitis $B(\mathrm{CHB})$ has been well established, HBV-DNA level is very strongly predictive of the risk of disease progression [5]. The viral load is probably a significant factor in the natural history of CHB infection, with active replication being at greater risk of disease progression than those without detectable HBV-DNA in serum $[6,7]$. CHB is characterized by the inflammatory liver disease of variable severity, $15 \%-40 \%$ of patients who have CHB infection progress to cirrhosis and end stage liver disease, and $25 \%$ of these later develop HCC $[8,9]$. In order to decrease the cost, the side effects and the probability of resistance, the timing of the initiation of the treatment is crucial. The most important indicator for the decision related to the treatment is the histology of the liver which is the best predictor for the prognosis of the disease [10]. Nevertheless, the relationship between serum HBV DNA level and liver histology remains controversial.

\section{Methods}

Total 301 chronic hepatitis B naive patients (HBs Ag positive more than six months) were studied. The patients were selected from those referred to Tehran Hepatitis Centre (THC) which is a referral centre for hepatitis in Tehran from January 2006 to September 2010. Patients with co-infection of $\mathrm{HIV}, \mathrm{HCV}$ and HDV infection were excluded. Informed consent was obtained from each patient. The HBV-DNA level, blood chemistry and complete blood count were tested by using standards commercially available assays. The Serum HBV-DNA level quantification was performed by PCR (Roche Diagnostics Kit, GmbH; UK) according to the manufacturer's instructions. The detection of HBV DNA ranged $10^{3}-10^{10}$ copies/mL. Percutaneus liver biopsy was performed in all patients. All histological preparations were examined by the single pathologist who was an expert in liver histopathology and was unaware of the clinical and viral HBVDNA status. Liver histology was graded according to the Ishak et al [11] scoring system, which includes a fibrosis score (0-6) and necroinflammatory score (0-18). The latter is the sum of four scores, piecemeal necrosis (0-4); confluent necrosis (0-6); focal lytic necrosis, apoptosis and focal inflammation (0-4); portal inflammation (0-4). We used the 
Statistical Package for the Social Sciences (SPSS) version 16 for analysis. Statistical methods included the chi and Fisher exact test, the T-test and ANOVA. A two-sided $p$ value of less than 0.05 was considered to be statistically significant.

\section{Results}

Among 301 patients, 212 (70.4\%) were male and 89 (29.6\%) were female. The mean age was $34.63 \pm 13.25$ years (min. 8 and max. 70 years). No significant differences were seen between the age of the male and female. HBe Ag was tested among 256 patients. Among them, 104 (40.6\%) were positive and $152(59.4 \%)$ were negative. Mean laboratory values were as follows: ALT 102.31 $\pm 214.21 \mathrm{IU} / \mathrm{L}$, AST $69 \pm 144.63 \mathrm{IU} / \mathrm{L}$ and HBV DNA level $1.35 \times 10^{8} \pm 1.05 \times 10^{9}$ copies $/ \mathrm{mL}$ and histological findings were: mean grade score was $5.54 \pm 3.26$ and mean fibrosis score $1.93 \pm 1.56$ (Table 1). $54 \%$ (17.9\%) patients had stage 0 and $7 \%$ (2.3\%) had stage IV (Figure 1), also $91 \%(30.2 \%)$ had mild grade and $4(1.3 \%)$ had severe grade (Figure 2).

Mean serum HBV-DNA level in $\mathrm{HBe} \mathrm{Ag}$ positive was $3.68 \times 10^{8} \pm 1.77 \times 10^{9}$ copies $/ \mathrm{mL}$ and in $\mathrm{HBe} \mathrm{Ag}$ negative patients was $7.77 \times 10^{6} \pm 4.54 \times 10^{7}$ copies $/ \mathrm{mL}(\mathrm{p}=0.041)$. No significant differences were seen between ALT and AST of HBe Ag positive and negative patients, mean ALT level of $\mathrm{HBe} \mathrm{Ag}$ positive patients was $124.12 \pm 257.27 \mathrm{IU} / \mathrm{L}$ and in $\mathrm{HBe} \mathrm{Ag}$ negative patients was $95.94 \pm 210.61 \mathrm{IU} / \mathrm{L}(\mathrm{p}>0.05)$. The mean AST level of $\mathrm{HBe} \mathrm{Ag}$ positive patients was $82.8 \pm 279.72 \mathrm{IU} / \mathrm{L}$ and in $\mathrm{HBe} \mathrm{Ag}$ negative patients was $64.12 \pm 136.52 \mathrm{IU} / \mathrm{L}$ $(\mathrm{p}>0.05)$.

Table 1. Patients' basic data, laboratory and histology findings

\begin{tabular}{lccc}
\hline & Minimum & Maximum & Mean \\
\hline Age (years) & 8 & 70 & $34.63 \pm 13.25$ \\
$\begin{array}{l}\text { Body mass in- } \\
\text { dex(BMI) }\end{array}$ & 13.3 & 43.85 & $24.47 \pm 4.27$ \\
AST (U/L) & 9 & 1600 & $69 \pm 144.63$ \\
ALT (U/L) & 6 & 2440 & $102.31 \pm 214.21$ \\
PLT & 19000 & 402000 & $195000 \pm 55274$ \\
PT & 11 & 17.6 & $13.9 \pm 1.07$ \\
INR & 1 & 1.8 & $1.07 \pm 0.13$ \\
Grade & 0 & 15 & $5.54 \pm 3.26$ \\
Stage & 0 & 6 & $1.93 \pm 1.56$ \\
HBV-DNA & 21 & $1.58 \times 10^{10}$ & $1.35 \times 108 \pm 1.05109$ \\
\hline
\end{tabular}

Figure 1. Frequency of staging

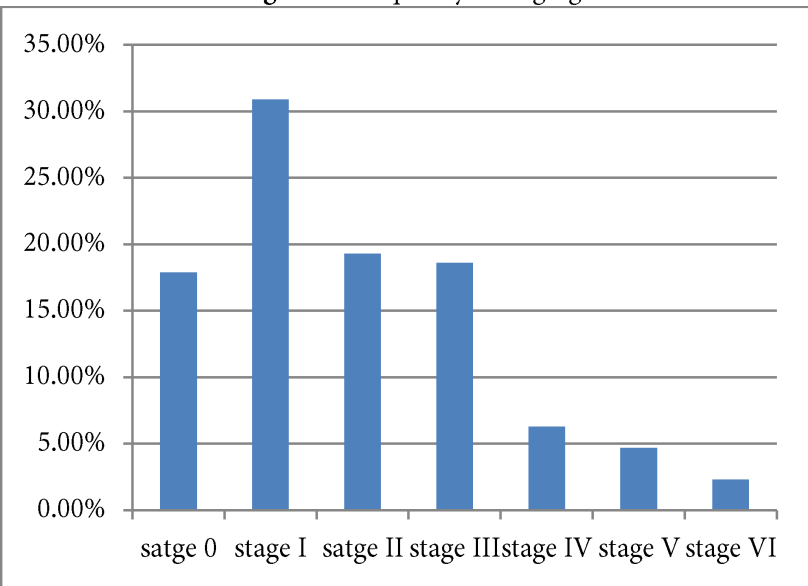

Figure 2. Frequency of grading

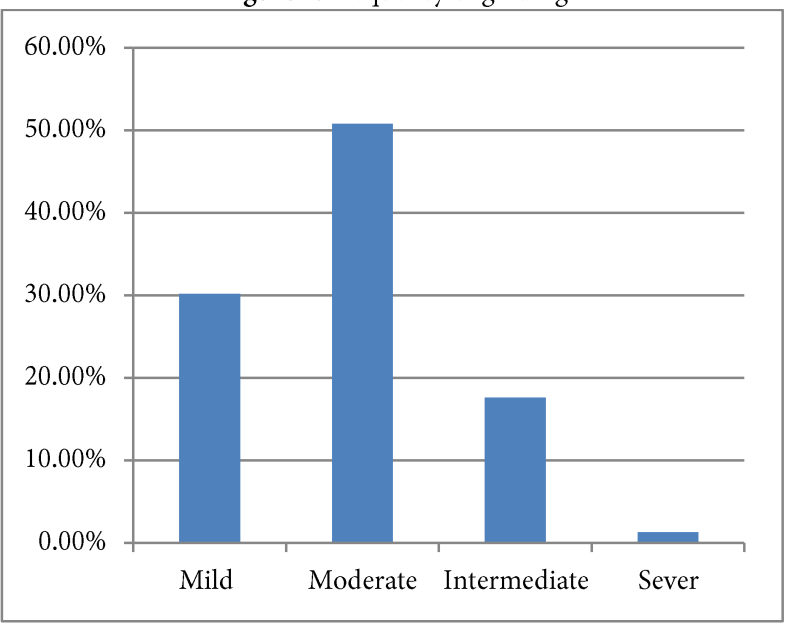

We divided patients in two groups: normal (ALT less than 40 $\mathrm{IU} / \mathrm{L}$ ) and abnormal (ALT more than $40 \mathrm{IU} / \mathrm{L}$ ) ALT groups. No differences were seen in serum HBV-DNA level between higher ALT and in less than $40 \mathrm{IU} / \mathrm{L}$ group. The mean serum HBV-DNA level of patients with normal ALT was $5.19 \times 10^{7} \pm 1.85 \times 10^{8}$ copies $/ \mathrm{mL}$ and in abnormal ALT patients it was $1.66 \times 10^{8} \pm 1.22 \times 10^{9}$ copies $/ \mathrm{mL}$. No significant differences were seen between different stages and grades of liver histology in HBV-DNA level. Mean serum HBV-DNA of patients with stage 0 was $1.96 \times 10^{8} \pm 1.15 \times 10^{9}$ copies $/ \mathrm{mL}$ and stage VI was $6.9 \times 10^{7} \pm 5.1 \times 10^{7}$ copies $/ \mathrm{mL}(\mathrm{P}>0.072)$ (Table 2$)$. Mean HBV-DNA level of patients with mild grade was $1.72 \times 10^{8} \pm 9 \times 10^{8}$ copies $/ \mathrm{mL}$ and in severe grade patients was $3.2 \times 10^{7} \pm 5.35 \times 10^{7}$ copies $/ \mathrm{mL}$ ( $\left.\mathrm{p}>0.05\right)$ (Table 3$)$.

Table 2. Comparison of serum HBV-DNA levels in different stages

\begin{tabular}{lccc}
\hline Stage & St. Deviation & Mean & P.value \\
\hline Stage 0 & $1.15 \times 10^{9}$ & $1.96 \times 10^{8}$ & \\
Stage I & $1.44 \times 10^{8}$ & $4.48 \times 10^{7}$ & \\
Stage II & $2.02 \times 10^{8}$ & $4.92 \times 10^{7}$ & \\
Stage III & $4.4 \times 10^{8}$ & $9.49 \times 10^{7}$ & $\mathrm{p}>0.072$ \\
Stage IV & $3.61 \times 10^{9}$ & $8.98 \times 10^{8}$ & \\
Stage V & $3.27 \times 10^{7}$ & $1.51 \times 10^{7}$ & \\
Stage VI & $5.1 \times 10^{7}$ & $6.9 \times 10^{7}$ & \\
\hline
\end{tabular}

Table 3. Comparison of serum HBV-DNA levels in different grades

\begin{tabular}{lccc}
\hline Grade & St. Deviation & Mean & P.value \\
\hline Mild & $9 \times 10^{8}$ & $1.72 \times 10^{8}$ & \\
Moderate & $1.3 \times 10^{9}$ & $5.08 \times 10^{9}$ & \\
Intermediate & $1.13 \times 10^{8}$ & $3.5 \times 10^{7}$ & $\mathrm{p}>0.05$ \\
Severe & $5.35 \times 10^{7}$ & $3.2 \times 10^{7}$ & \\
\hline
\end{tabular}

\section{Discussion}

Liver biopsy has several well-documented drawbacks, including sampling error, variability in pathologist interpretation, cost, and morbidity. We aimed to investigate the relationship between the serum HBV-DNA level and the histology of the liver, which is considered to be the most important prognostic indicator. Serum HBV-DNA level was higher in $\mathrm{HBe} \mathrm{Ag}$ positive patients in comparison with $\mathrm{HBe}$ Ag negative patients. In our study, the HBV DNA level did not correlate with the stage between $\mathrm{HBeAg}$ positive and negative patients with CHB, as previously reported in Shao et al.'s [12] 
study that had no correlation between liver histology and HBV DNA level in $\mathrm{HBe} \mathrm{Ag}$ positive and negative patients. Additionally Ghanaei et al [13] reported no significant relationship between the serum HBV DNA level and the liver histological stage, gender, age, BMI, or HBeAg.. Additionally, in our study there was a correlation between the HBV DNA level and the liver histology in grading HBe Ag negative patients; however, there wasn't any difference in the HBV-DNA level and staging in either $\mathrm{HBe} A g$ positive or negative patients. Higher stage and grade had a higher AST and ALT level however; there was no statistically significant difference in the AST and ALT level in different stages and grades of liver histology. We found that different stages and grades didn't differ in normal ALT groups. In contrast, Vardar et al [14] reported that normal ALT always indicated a lower grade of histology, but was not associated with lower fibrosis scores. Also the HBV DNA level didn't differ in normal ALT patients in comparison with the abnormal ALT level. When we divided patients into two groups, grade $\leq 4$ and $>4$, there was a significant difference in the AST and ALT levels and patients with grades more than 4 had a higher ALT and AST level without any differences in the serum HBV DNA level. In our study there was no relation between the HBV DNA levels, AST and ALT with liver histology. One of the limitations of this study was the difference in stages of the disease which the patients were possibly facing. Thus, it is possible that some were in immune tolerance phases (with high DNA and low ALT) and others were in immune clearance phases (high but relatively lower DNA and high ALT). If a study includes patients in different phases of the disease, it would be difficult to identify an association between the HBV DNA levels and ALT, even if a relation exists within a particular type of patient. Another limitation was related to the method of DNA count. We used simple means for HBV DNA analysis. HBV DNA levels are on log scale and hence either a geometric mean or mean log DNA levels should be used for comparisons. However, a previous study [15] reported that the best model for predicting significant inflammation included the variables age, HBV DNA levels, AST and albumin, and said that in $\mathrm{HBeAg}$ positive patients no factor could accurately predict the stages of liver fibrosisand the best factor for predicting significant inflammation was AST.

\section{Acknowledgements}

We would like to thank Mr. najafabadi for his collaboration.

\section{Authors' Contribution}

All authors contributed in all the steps of this study.

\section{Funding/support}

This project was support by the Baqiyatallah University of Medical Sciences.

\section{Financial Discloser}

Not declared.

\section{References}

1. Lok AS, McMahon BJ. Chronic Hepatitis B: update of recommendations. Hepatology. 2004;39(3):857-61.

2. Takkenberg RB, Weegink CJ, Zaaijer HL, Reesink HW. New developments in antiviral therapy for chronic hepatitis B. Vox Sang. 2010;98(4):481-94.

3. Chen CJ, Wang LY, Yu MW. Epidemiology of hepatitis B virus infection in the Asia-Pacific region. J Gastroenterol Hepatol. 2000;15 Suppl:E3-6.

4. alavian SM, Hajarizadeh B, Ahmadzad-Asl M, Kabir A, Bagheri Lankarani K. Hepatitis B Virus Infection in Iran: A Systematic Review. Hepat Mon. 2008;8(4):281-94.

5. Chen CJ, Iloeje UH, Yang HI. Long-term outcomes in hepatitis B: the REVEAL-HBV study. Clin Liver Dis. 2007;11(4):797-816, viii.

6. Chen CJ, Yang HI, Su J, Jen CL, You SL, Lu SN, et al. Risk of hepatocellular carcinoma across a biological gradient of serum hepatitis B virus DNA level. Jama. 2006;295(1):65-73

7. Iloeje UH, Yang HI, Su J, Jen CL, You SL, Chen CJ. Predicting cirrhosis risk based on the level of circulating hepatitis B viral load. Gastroenterology. 2006;130(3):678-86.

8. Wright TL. Introduction to chronic hepatitis B infection. Am J Gastroenterol. 2006;101 Suppl 1:S1-6.

9. Sanchez-Tapias JM, Costa J, Mas A, Bruguera M, Rodes J. Influence of hepatitis B virus genotype on the long-term outcome of chronic hepatitis B in western patients. Gastroenterology. 2002;123(6):184856.

10. Lok AS, McMahon BJ. [AASLD Practice Guidelines. Chronic hepatitis B: update of therapeutic guidelines]. Rom J Gastroenterol. 2004;13(2):150-4.

11. Ishak K, Baptista A, Bianchi L, Callea F, De Groote J, Gudat F, et al. Histological grading and staging of chronic hepatitis. J Hepatol. 1995;22(6):696-9.

12. Shao J, Wei L, Wang H, Sun Y, Zhang LF, Li J, et al. Relationship between hepatitis B virus DNA levels and liver histology in patients with chronic hepatitis B. World J Gastroenterol. 2007;13(14):21047.

13. Mansour-Ghanaei F, Rafiei R, Joukar F, Naghipour M, Besharati S, Aminian K, et al. Relationship between serum HBV DNA level and liver histology in HBV carriers with normal ALT in Guilan province, Iran. Med Sci Monit. 2010;16(3):BR97-101.

14. Vardar R, Gunsar F, Sertoz R, Ozacar T, Nart D, Barbet FY, et al. The relationship between HBV-DNA level and histology in patients with naïve chronic HBV infection. Hepatogastroenterology. 2010;57(101):908-12.

15. Mohamadnejad M, Montazeri G, Fazlollahi A, Zamani F, Nasiri J, Nobakht $\mathrm{H}$, et al. Noninvasive markers of liver fibrosis and inflammation in chronic hepatitis B-virus related to liver disease. Am J Gastroenterol. 2006;101(11):2537-45. 